\title{
Range contraction in a beluga whale population
}

\author{
David J. Rugh*, Kim E. W. Shelden, Roderick C. Hobbs \\ National Oceanic and Atmospheric Administration, National Marine Fisheries Service, Alaska Fisheries Science Center, \\ National Marine Mammal Laboratory, 7600 Sand Point Way NE, Seattle, Washington 98115, USA
}

\begin{abstract}
The small, isolated population of beluga whales Delphinapterus leucas in Cook Inlet, Alaska, USA, has had a distinct contraction in range over the past 3 decades. This contraction is a function of a decline in abundance, evidently caused, at least in part, by high takes during unregulated subsistence hunting. During the 1990s, hunting resulted in takes of over 50 whales $\mathrm{yr}^{-1}$, all of which occurred in the northern portion of Cook Inlet. Concurrent with the decline in abundance, sightings became rare in the southern inlet, even though human impact had been relatively low there. Curiously, the density of whales in the northern inlet remained high in spite of the hunts. Significant changes in beluga whale distribution are evident across 3 periods: 1978-1979 (the earliest well-documented data); 1993-1997 (during the recorded decline in abundance); and 1998-2008 (when hunting was regulated and recovery was anticipated). The center of the summer range of beluga whales contracted northeastward into upper Cook Inlet from the $1970 \mathrm{~s}$ to the $1990 \mathrm{~s}(38 \mathrm{~km} ; \mathrm{p}=$ 0.042 ) and continued into the 2000s (total of $53 \mathrm{~km}$; $\mathrm{p}=0.022$ ) with a longitudinal shift east towards Anchorage (the largest city and port in Alaska) occurring between the 1990s and 2000s $(17 \mathrm{~km} ; \mathrm{p}=$ $0.025)$. The result is a reduced range $\left(>7000\right.$ to $\left.<3000 \mathrm{~km}^{2}\right)$ in all but the area with the highest degree of human disturbance. If and when the Cook Inlet beluga whale population begins to increase, a reoccupation of peripheral habitats may be the first indication of recovery.
\end{abstract}

KEY WORDS: Range contraction - Abundance decline $\cdot$ Beluga whale Delphinapterus leucas . Cook Inlet $\cdot$ Human disturbance

\section{INTRODUCTION}

A small, isolated population of beluga whales Delphinapterus leucas in Cook Inlet, Alaska, USA, is separated by the Alaska Peninsula (>900 km long) from other beluga whale populations in western Alaska, including beluga whales that summer in Bristol Bay, the eastern Bering Sea, eastern Chukchi Sea, and the Beaufort Sea; all but the Cook Inlet population spend winters in the Bering Sea (O'Corry-Crowe et al. 1997, Laidre et al. 2000). Other beluga whale populations around Alaska are known to migrate thousands of kilometers annually (Hazard 1988), yet the beluga whales in Cook Inlet, similar to those in Bristol Bay roughly $250 \mathrm{~km}$ to the west, appear closely tied to a relatively small area. Genetic analysis indicates there has been no significant exchange between Cook Inlet and other populations for over 10000 yr (O'Corry-Crowe et al. 1997), since the re- treat of the last ice age. Although beluga whales have occasionally been seen in coastal areas around the Gulf of Alaska (Laidre et al. 2000), there is no evidence that beluga whales in Cook Inlet have seasonal migrations in and out of the inlet (Hobbs et al. 2005). In fact, beluga whales in Cook Inlet are found during spring and summer in dense groups across a fairly limited range at the mouths of rivers and in shallow waters through which anadromous fish swim to spawning streams (Rugh et al. 2000, Goetz et al. 2007). Alaska Native subsistence hunters found the whales predictably in these areas (Huntington 2000) and have hunted them for hundreds of years, apparently at low levels (Mahoney \& Shelden 2000). However, in the 1990s, takes rose to over $50 \mathrm{yr}^{-1}$ (Mahoney \& Shelden 2000), which resulted in a $50 \%$ decline in abundance in just the first $4 \mathrm{yr}$ of documentation, with numbers dropping from 653 (coefficient of variation, CV = 0.43) whales in 1994 to $347(\mathrm{CV}=0.29)$ in 1998 
(Hobbs et al. 2000a). In 1999, hunters voluntarily suspended the hunt, and since then the hunt has been regulated by the National Marine Fisheries Service (NMFS) at 0 to 2 whales $\mathrm{yr}^{-1}$ (64 Federal Register [FR] 56298; Hobbs et al. 2008).

Evidence of the decline in abundance first came from sightings data during aerial surveys of Cook Inlet, which showed that beluga whales had become rare in the southern portion of the inlet by the 1990s (Rugh et al. 2000). The abundance trend was evident in counts of whales made during routine, systematic aerial surveys conducted by NMFS in June or July each year since 1994 (although NMFS surveys began in 1993, the first year for which an abundance estimate was calculated was 1994; Rugh et al. 2000, 2005). These counts were developed through video analysis of multiple aerial passes in the vicinity of each whale group. Corrections were then applied for estimates of groups missed, whales out of sight during aerial passes, and whales missed within the viewing perimeter of the camera (Hobbs et al. 2000b). The documented decline in abundance was adequately explained by the estimated mortalities from the Native subsistence hunt for the same period (Hobbs et al. 2008). However, to date, i.e. $10 \mathrm{yr}$ after hunting regulations were introduced, there has been no evidence of an increase in beluga whale abundance (Hobbs et al. 2008). Accordingly, the population has been listed as Endangered under the US Endangered Species Act (NOAA 2008) and as Critically Endangered by the International Union for the Conservation of Nature (Lowry et al. 2006).

Declines in abundance of wildlife populations are often reflected in changes in distribution. These changes are sometimes manifested as (1) a shift away from impacted areas (e.g. Gill et al. 1996, 2001); (2) a contraction in range towards existing high-abundance areas (e.g. Lawton 1993, Brown 1995); or (3) persistence of populations peripheral to, or isolated from, disturbance (e.g. Channell \& Lomolino 2000). As numbers of beluga whales in Cook Inlet declined, sightings became increasingly rare in portions of the inlet, yet the remaining whales still occupy areas where human disturbance has been and continues to be, the highest (Moore et al. 2000). This pattern of distributional change represents the second case listed above. Here, we describe this range contraction and discuss the implications for the conservation and recovery of this depleted, isolated population.

\section{MATERIALS AND METHODS}

Aerial surveys of beluga whales in Cook Inlet took place sporadically from the 1960s through the 1980s until systematic annual surveys began in 1993 (Rugh et al. 2000). Our analysis uses results from only those surveys with documented effort that included both the upper (north of East and West Forelands; $60^{\circ} 45^{\prime} \mathrm{N}$ ) and lower (or southern) portions of Cook Inlet. The time series for examining inter-annual distributional changes was restricted to surveys that were conducted in June or July (when the majority of surveys took place) to minimize seasonal changes in whale distribution, such as might occur with the presence of sea ice in winter (Rugh et al. 2004). Good documentation is available for aerial surveys conducted on 18 June 1978 and 18 to 22 June 1979 (Alaska Department of Fish and Game unpubl. data) and from the NMFS surveys starting in 1993 (Rugh et al. 2000, 2005, NMFS unpubl. data). Each of the surveys in the 1970s was a single sample of the study area, but the NMFS surveys (from 1993 to 2008) covered 4 to $10 \mathrm{~d}$ periods each year and included 3 to 7 repetitions of coastal flights around the upper inlet plus 1 to $2 \mathrm{~d}$ dedicated to surveying the lower inlet. Although these annual surveys included transects across the inlet, virtually all beluga whales were found proximal to coastal areas; therefore, the surveys have emphasized thorough coverage of the shores around Cook Inlet, and each year multiple flights have been made in the upper inlet where whales are found consistently. Results from NMFS surveys were weighted by number of surveys in each region; that is, for each series of years in this analysis, the number of sightings was divided by the number of flights through a region, countering the problem of changes in effort between years. The regions used in this analysis of Cook Inlet, based on where beluga whale sightings have occurred, are Trading Bay, the Susitna Delta (Trading Bay to Knik Arm), Knik Arm, Turnagain Arm, Kachemak Bay, Tuxedni Bay, and Iniskin Bay (see Figs. 1 to 3).

Data were examined in 3 periods: 1978-1979 (the earliest well documented dataset); 1993-1997 (during a decline in abundance); and 1998-2008 (when hunting was regulated and recovery was anticipated). Distributional changes were calculated (using the 'Directional Distribution' tool in ArcView) by determining the proximity of whales relative to a central location computed for all whale sightings observed within each of the 3 periods. These statistics were weighted by the number of animals in each group. The distribution of beluga whales around each central location for each period was calculated at $1 \mathrm{SD}$ (capturing about $68 \%$ of the whales) and 2 SD (capturing about $95 \%$ ). We compared successive central locations among the 3 periods by applying Student's $t$-tests (at an alpha level of $5 \%$ ) using the long axis of each SE ellipse. Degrees of freedom are estimated as 2 less than the number of groups averaged in the distribution. 


\section{RESULTS}

Beluga whales were distributed over a relatively large area in June 1978 and 1979 (2 SD area occupied = $7226 \mathrm{~km}^{2}$ ), with the central location occurring between the McArthur and Beluga rivers (Fig. 1). The area of highest concentration included the northwest portion of Cook Inlet from Drift River to the mouth of the Susitna River. In 1993-1997, the central location was $39 \mathrm{~km}$ to the northeast relative to sightings in 1978-1979; this was a shift towards the mouth of the Susitna River, and the area of highest concentration was smaller and more northerly, covering $3715 \mathrm{~km}^{2}$ from the Susitna Delta to the entrance of Knik Arm (Fig. 2). In 1998-2008, the central location was farther east again $(53 \mathrm{~km})$, between the Little Susitna River and Fire Island (Fig. 3), and the area of highest concentration $\left(2806 \mathrm{~km}^{2}\right)$ shifted east, extending from the mouth of the Susitna River into Knik Arm and toward Turnagain Arm. Changes in the central locations over the 3 periods were significant: 1978-1979 to

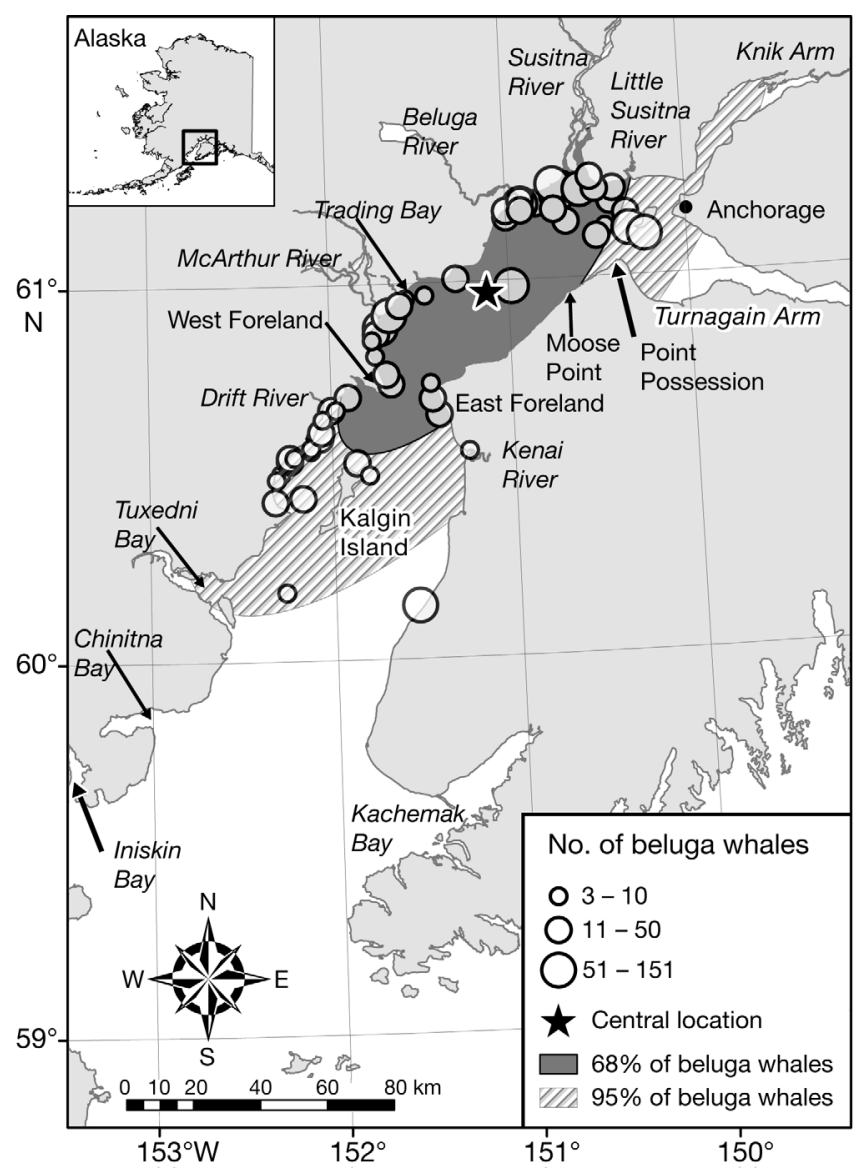

Fig. 1. Delphinapterus leucas. Areas occupied by beluga whales in Cook Inlet, Alaska, in June/July 1978-1979. The distribution of beluga whales around each central location for each period was calculated at $1 \mathrm{SD}$ (capturing ca. $68 \%$ of the whales) or $2 \mathrm{SD}(95 \%)$

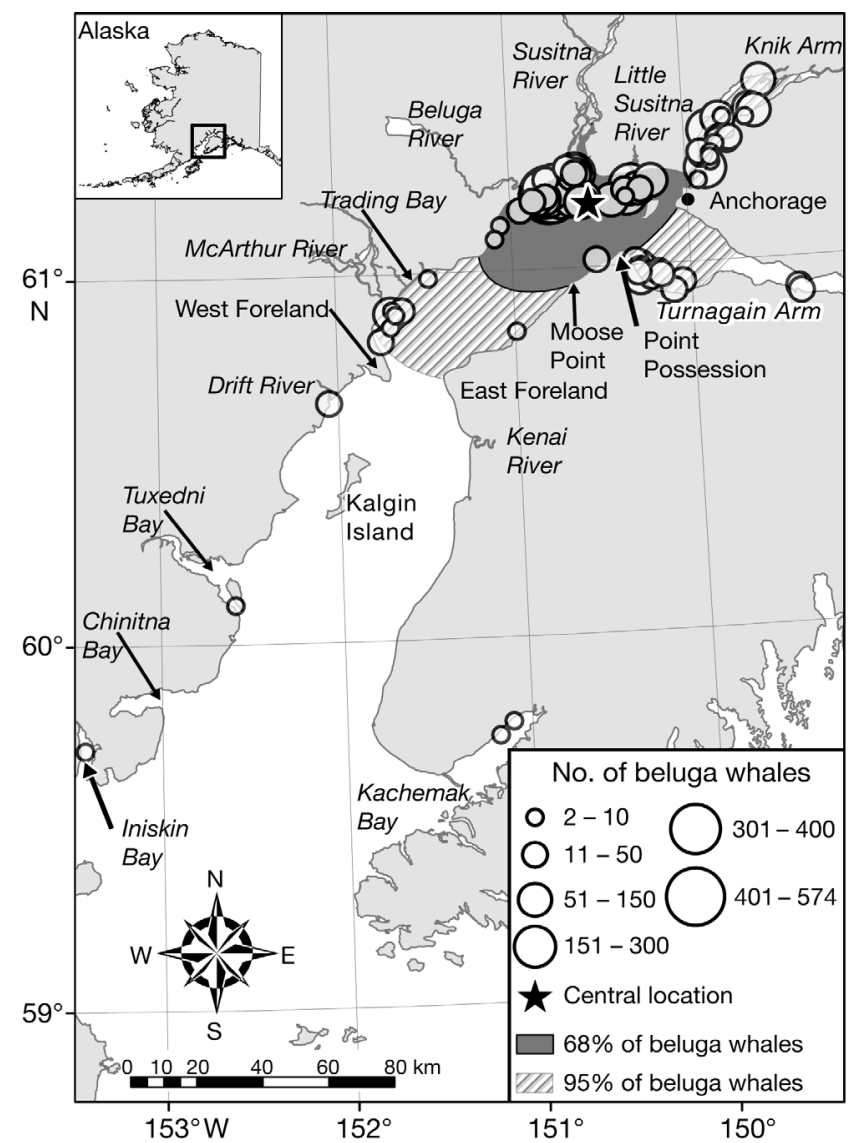

Fig. 2. Delphinapterus leucas. Areas occupied by beluga whales in Cook Inlet, Alaska, in June/July 1993-1997. See Fig. 1 for further details

1993-1997 ( $\mathrm{p}=0.04$, a $39 \mathrm{~km}$ shift to the northeast), $1978-1979$ to $1998-2008(\mathrm{p}=0.02$; a $53 \mathrm{~km}$ shift to the northeast), and 1993-1997 to 1998-2008 ( $\mathrm{p}=0.04$; a $17 \mathrm{~km}$ shift to the east). Changes were large enough between successive periods to have a probability of less than $5 \%$ of being from the same distribution, that is, of not being significantly different.

In all 3 periods, more beluga whales were in the Susitna Delta area (defined here as being from north of Trading Bay to the Little Susitna River) than in other areas, such as Chickaloon Bay/Turnagain Arm, Knik Arm, or the central or southern portions of Cook Inlet. The average annual fraction of beluga whales seen in the Susitna area ranged from 17 to $91 \% \mathrm{yr}^{-1}$ (mean = $51 \%$; SD $=20 \%$ ). No significant change was evident through the sample period 1978-2008 (mean $\mathrm{p}=0.26$; $\mathrm{SD}=0.08 ;$ Table 1 ). Although the proportion of the population using the Susitna area did not change, the number of animals there dropped significantly $(\mathrm{p}<$ 0.01) after the Cook Inlet beluga whale population declined $(1993-1997$ average $=332 ; \mathrm{SD}=118$; $1998-2008$ average $=175 ; \mathrm{SD}=78)($ Table 2$)$. 


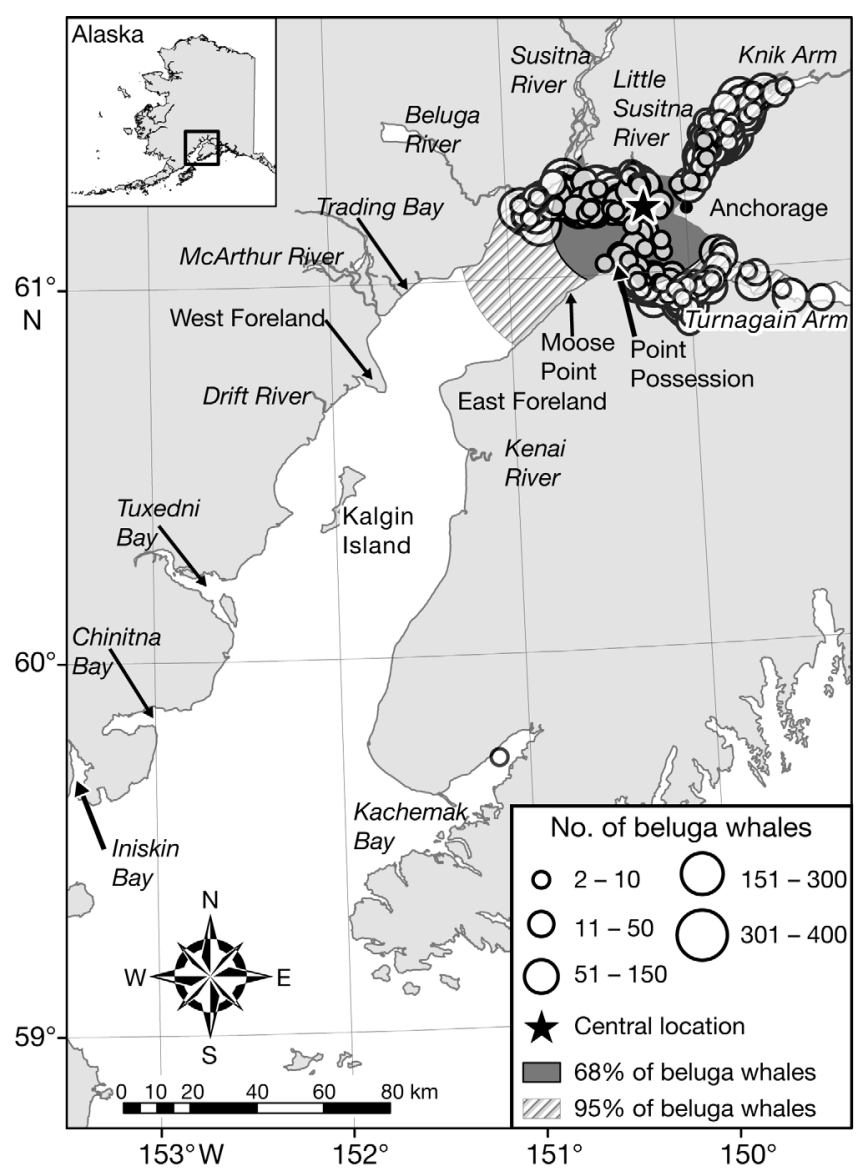

Fig. 3. Delphinapterus leucas. Areas occupied by beluga whales in Cook Inlet, Alaska, in June 1998-2008. See Fig. 1 for further details

Table 1. Delphinapterus leucas. Results of $t$-tests using paired samples and assuming unequal variances, showing that the percent of beluga whales found in the Susitna Delta region relative to all of Cook Inlet did not change through time. Data are based on the estimated totals of whales in the area, correcting for whales missed in the search area

\begin{tabular}{|c|c|c|c|c|}
\hline & \multicolumn{2}{|c|}{ p values } & \multirow{2}{*}{\multicolumn{2}{|c|}{$\begin{array}{l}\text { Belugas in the } \\
\text { Susitna area }\end{array}$}} \\
\hline & \multirow{2}{*}{ 1993-1997 } & \multirow[t]{2}{*}{ 1998-2008 } & & \\
\hline & & & $\mathrm{n}$ & $\%$ \\
\hline 1978-1979 & 0.19 & 0.35 & 251 & 43 \\
\hline 1993-1997 & - & 0.23 & 337 & 58 \\
\hline $1998-2008$ & - & - & 172 & 50 \\
\hline
\end{tabular}

\section{DISCUSSION}

Small, isolated populations are highly vulnerable to extinction when subjected to excessive, chronic impacts as well as to episodic, catastrophic events (e.g. a new predator, disease, or sudden environmental change), especially when a population occurs in a few
Table 2. Delphinapterus leucas. A comparison of the areas shown as the $95 \%$ ranges in Figs. 1 to 3 (2 SD around the central range calculation) using the earliest sightings distribution of beluga whales as representative of the full range

\begin{tabular}{|ccc|}
\hline $\begin{array}{c}\text { Sample } \\
\text { periods }\end{array}$ & $\begin{array}{c}95 \% \text { of } \\
\text { beluga range } \\
\left(\mathrm{km}^{2}\right)\end{array}$ & $\begin{array}{c}\text { Area used relative } \\
\text { to 1978-1979 } \\
\text { range }(\%)\end{array}$ \\
\hline $1978-1979$ & 7226 & 100 \\
$1993-1997$ & 3715 & 51 \\
$1998-2008$ & 2806 & 39 \\
\hline
\end{tabular}

dense groups. Principal ways to avoid extinction when persistent detrimental impacts exceed the reproductive potential of a population are to emigrate (assuming adequate habitat can be found elsewhere) or to replenish the population through immigration. In our example of beluga whales in Cook Inlet, the animals have remained in an area of high human impact (the north end of the inlet, near Anchorage, where hunting has occurred [Mahoney \& Shelden 2000] and industrial growth prevails [Moore et al. 2000]) and have essentially disappeared from other previously used habitats (in the middle and southern portions of the inlet). The high proclivity of these whales for staying in the northern reaches of Cook Inlet, for whatever reason, means it is unlikely that they will emigrate to another area (Laidre et al. 2000), since it seems they have not done so for thousands of years (O'Corry-Crowe et al. 1997). Also, there is no realistic potential for beluga whales from other populations to immigrate into Cook Inlet (Laidre et al. 2000). This raises concerns about vulnerability to extinction (Stacey \& Taper 1992, Hobbs et al. 2008).

Similar examples of beluga whale populations impacted by unregulated hunting and other anthropogenic disturbances have been documented in the St. Lawrence River of eastern Canada (Reeves \& Mitchell 1984, Kingsley 1998) and eastern Hudson Bay, Canada (Caron \& Smith 1990). In these examples, the whale populations remained in their familiar ranges in spite of pressures that severely lowered their numbers.

Other whale species have shown a similar tenacity to a home range even though whaling nearly extirpated them in that area: North Atlantic right whales Eubalaena glacialis in northeastern US waters (Reeves et al. 1999); North Pacific right whales E. japonica in the southeastern Bering Sea (Clapham et al. 2004, Shelden et al. 2005); gray whales Eschrichtius robustus off Baja California (Rice \& Wolman 1971); humpback whales Megaptera novaeangliae in the Caribbean Sea (Reeves et al. 2001); and killer whales Orcinus orca in Puget Sound, Washington, USA (Olesiuk et al. 1990). 
There are several hypotheses which may explain the documented range contraction of beluga whales in Cook Inlet: (1) habitat change, such as prey availability; (2) avoidance of killer whales Orcinus orca; or (3) the use of spatially limited optimal habitat by the remnant population of beluga whales. The following paragraphs elaborate on these hypotheses.

Hypothesis 1: It is conceivable that fish runs have deteriorated in the southern portion of Cook Inlet more so than in the north or that fish runs have diminished throughout the inlet and only in the shallow river channels in the northern areas is it still relatively efficient to catch fish (Goetz et al. 2007). Around Cook Inlet there are numerous anadromous fish runs on which beluga whales prey, including eulachon Thaleichthys pacificus and 5 species of salmon: chinook Oncorhynchus tshawytscha, pink O. gorbuscha, coho O. kisutch, sockeye O. nerka, and chum O. keta (Moulton 1997, Moore et al. 2000). However, lacking long-term, consistent datasets, it is difficult to assess potential impacts of changes in prey availability, if there were any. This is true not only for species of commercial interest (i.e. salmon) but for non-commercial species such as eulachon, which could be important for beluga whales (Goetz et al. 2007). The timing, location, and abundance of these fish runs can be elemental to beluga whale distribution.

Hypothesis 2: Killer whale predation on beluga whales in Cook Inlet is not uncommon, which leads to the speculation that beluga whales retreat to the northern reaches of Cook Inlet to avoid killer whales (Shelden et al. 2003). This provides protection both by being in an isolated body of water and in that beluga whales can hide from killer whales by entering shallow channels over mudflats, sometimes to the point of being stranded (Vos \& Shelden 2005). However, predation on beluga whales has often been documented in the northern portion of Cook Inlet (Shelden et al. 2003), so that this area in and of itself is not a complete sanctuary. Furthermore, to assume that killer whales are the primary factor driving beluga whale distribution would not explain why so many beluga whales were seen in the southern portion of the inlet in the past, unless killer whale presence has increased or unless large numbers of beluga whales in the past would have provided a sense of protection from predators. It seems, then, that the selection of range on the part of the beluga whales is a balance between prey availability and predator avoidance; when the former is a challenge, such as when the whale population is large and competing vigorously for available prey, then predator avoidance is a lower priority, and some whales explore other habitat (southern Cook Inlet) where fish are available but killer whales are more common.
Hypothesis 3: The use of a limited range by the remnant population is consistent with the history of this population. Indeed, the range retraction appears exactly as one would expect under the model of an emptying basin (MacCall 1990). For instance, the number of beluga whales in the Susitna Delta was consistently higher than in any other region of the inlet, even though this was the area in which most hunting occurred (Mahoney \& Shelden 2000) and although it is not far from ongoing coastal zone development near Anchorage (Moore et al. 2000). This does not explain why the upper inlet is preferred, but it is intuitive that poorer quality habitat would be abandoned when population abundance, and thus density-dependent competition, diminishes. This is particularly true for social animals like beluga whales that frequently cluster in large groups and appear to maintain inherited behavior patterns relative to range and movements, a factor which may have management implications in regard to development within key areas.

The concentration of these whales adjacent to an industrialized area is surprising. Numerous studies of large mammals (reviewed by Frid \& Dill 2002) document the detrimental effects of human-caused disturbance on behavior, reproductive success, and parental investment. The effects of disturbance, particularly unregulated hunting, are analogous to predation risk. Theoretically, there is a tradeoff between predation risk and acquiring resources, such as feeding, and animals are expected to inhabit areas that minimize the ratio of risk to net energy gain (Frid \& Dill 2002, Wirsing et al. 2008). The sum of the evidence is that the net benefit of changing to an alternative habitat has not outweighed the cost of remaining in a disturbed area (Gill et al. 2001) as long as the carrying capacity of the preferred area is not exceeded.

Channell \& Lomolino (2000) reviewed studies of spatial dynamics during range contractions as small populations approached extinction. The center of a species' range is where population density is likely to be larger and less variable because this preferred habitat is more suitable. Then, as a species approaches extinction, its range is likely to contract until the last animals are found in the center of its historic range. However, this approach assumes a ubiquitous and uniform cause for the decline. A less uniform impact might effect local losses without being evident across the full range of a population, assuming a tenacity of parts of the population to certain areas. By contrast, beluga whales in Cook Inlet were impacted by chronic hunting mostly in the northern portion of the inlet (Mahoney \& Shelden 2000), the same area where whales are still found in relatively high abundance. As suggested by Brown (1995), habitats where species were abundant prior to a decline 'should on average remain relatively more favourable.' 
The distribution of animals can serve as a gauge of a population's growth or decline. For instance, during a period of declining abundance of beluga whales in Cook Inlet, the first clear evidence was in a contracting distribution of whale sightings, well before there was a statistically significant decline in abundance. If and when this whale population begins to increase, a reoccupation of peripheral habitats may be the first indication of recovery.

Acknowledgements. We are grateful to the Alaska Department of Fish and Game, K. Pitcher in particular, for providing us with the beluga whale sighting data collected during aerial surveys in the 1970 s conducted by N. Murray and D. Calkins. B. Mahoney (NMFS) and K. Laidre (Polar Science Center, University of Washington) provided input on earlier versions of this work. NMFS aerial surveys were conducted under the Marine Mammal Protection Act Scientific Research Permit Nos. 791, 782-1360, and 782-1719. Helpful reviews of this document were provided by L. Fritz, P. Wade, and P. Clapham, all of the National Marine Mammal Laboratory, NMFS, and 6 anonymous reviewers. Reference to trade names does not imply endorsement by NMFS, NOAA.

\section{LITERATURE CITED}

Brown J (1995) Macroecology. University of Chicago Press, Chicago, IL

Caron L, Smith T (1990) Philopatry and site tenacity of belugas, Delphinapterus leucas, hunted by the Inuit at the Nastapoka estuary, eastern Hudson Bay. In: Smith T, St Aubin D, Geraci J (eds) Advances in research on the beluga whale, Delphinapterus leucas. Can Bull Fish Aquat Sci 224:69-79

Channell R, Lomolino M (2000) Trajectories to extinction: spatial dynamics of the contraction of geographical ranges. J Biogeogr 27:169-179

Clapham P, Good C, Quinn S, Reeves R, Scarff J, Brownell R (2004) Distribution of North Pacific right whales (Eubalaena japonica) as shown by 19th and 20th century whaling catch and sighting records. J Cetacean Res Manag 6:1-6

Frid A, Dill L (2002) Human-caused disturbance stimuli as a form of predation risk. Conserv Ecol 6:11

Gill J, Sutherland W, Watkinson A (1996) A method to quantify the effects of human disturbance for animal populations. J Appl Ecol 33:786-792

Gill J, Norris K, Sutherland W (2001) Why behavioural responses may not reflect the population consequences of human disturbance. Biol Conserv 97:265-268

Goetz K, Rugh D, Read A, Hobbs R (2007) Habitat use in a marine ecosystem: beluga whales Delphinapterus leucas in Cook Inlet, Alaska. Mar Ecol Prog Ser 330:247-256

Hazard K (1988) Beluga whale, Delphinapterus leucas. In: Lentfer J (ed) Selected marine mammals of Alaska: species accounts with research and management recommendations. Marine Mammal Commission, Washington, DC, p 195-235

Hobbs R, Rugh D, DeMaster D (2000a) Abundance of beluga whales, Delphinapterus leucas, in Cook Inlet, Alaska, 1994-2000. Mar Fish Rev 62:37-45

Hobbs R, Waite J, Rugh D (2000b) Beluga, Delphinapterus leucas, group sizes in Cook Inlet, Alaska, based on observer counts and aerial video. Mar Fish Rev 62:46-59
Hobbs R, Laidre K, Vos D, Mahoney B, Eagleton M (2005) Movements and area use of belugas, Delphinapterus leucas, in a subarctic Alaskan estuary. Arctic 58:331-340

Hobbs R, Shelden K, Rugh D, Norman S (2008) Status review and extinction assessment of Cook Inlet belugas (Delphinapterus leucas). AFSC Proc Rep 2008-02. Alaska Fisheries Science Center, National Marine Fisheries Service, NOAA, Seattle, WA

Huntington $H$ (2000) Traditional knowledge of the ecology of beluga whale, Delphinapterus leucas, in Cook Inlet, Alaska. Mar Fish Rev 62:134-140

Kingsley M (1998) Population index estimates for the St. Lawrence belugas, 1973-1995. Mar Mamm Sci 14: 508-530

Laidre K, Shelden K, Rugh D, Mahoney B (2000) Beluga, Delphinapterus leucas, distribution and survey effort in the Gulf of Alaska. Mar Fish Rev 62:27-36

> Lawton J (1993) Range, population abundance and conservation. Trends Ecol Evol 8:409-413

Lowry L, O'Corry-Crowe G, Goodman D (2006) Delphinapterus leucas (Cook Inlet population). In: IUCN 2006. 2006 IUCN Red List of Threatened Species, Gland. Available at www.iucnredlist.org/apps/redlist/details/61442/0

MacCall A (1990) Dynamic geography of marine fish populations. University of Washington Press, Seattle, WA

Mahoney B, Shelden K (2000) Harvest history of belugas, Delphinapterus leucas, in Cook Inlet, Alaska. Mar Fish Rev 62:124-133

Moore S, Shelden K, Litzky L, Mahoney B, Rugh D (2000) Beluga, Delphinapterus leucas, habitat associations in Cook Inlet, Alaska. Mar Fish Rev 62:60-80

Moulton L (1997) Early marine residence, growth, and feeding by juvenile salmon in northern Cook Inlet, Alaska. Alsk Fish Res Bull 4:154-177

NOAA (National Oceanic and Atmospheric Administration) (2008) Federal Register/ 73:205 Oct 22, 2008 / Rules and regulations. 50 CFR Part 224 [Docket No. 081014135781371-01] RIN 0648-XL30 Federal Register, Washington, DC

O'Corry-Crowe G, Suydam R, Rosenberg A, Frost K, Dizon A (1997) Phylogeography, population structure and dispersal patterns of the beluga whale Delphinapterus leucas in the western Nearctic revealed by mitochondrial DNA. Mol Ecol 6:955-970

Olesiuk P, Bigg M, Ellis G (1990) Life history and population dynamics of resident killer whales (Orcinus orca) in the coastal waters of British Columbia and Washington State. Rep Int Whal Comm (Spec Issue 12):209-243

Reeves R, Mitchell E (1984) Catch history and initial population of white whales (Delphinapterus leucas) in the river and Gulf of St. Lawrence, eastern Canada. Nat Can 111: 63-121

Reeves R, Breiwick J, Mitchell E (1999) History of whaling and estimated kill of right whales, Balaena glacialis, in the northeastern United States, 1620-1924. Mar Fish Rev 61: $1-36$

Reeves R, Swartz S, Wetmore S, Clapham P (2001) Historical occurrence and distribution of humpback whales in the eastern and southern Caribbean Sea, based on data from American whaling logbooks. J Cetacean Res Manag 3: 117-129

Rice D, Wolman A (1971) The life history and ecology of the gray whale (Eschrichtius robustus). Am Soc Mammal Spec Publ 3

Rugh D, Shelden K, Mahoney B (2000) Distribution of belugas, Delphinapterus leucas, in Cook Inlet, Alaska, during June/July 1993-2000. Mar Fish Rev 63:6-21 
Rugh D, Mahoney B, Smith B (2004) Aerial surveys of beluga whales in Cook Inlet, Alaska, between June 2001 and June 2002. US Dept Commerce. NOAA Tech Memo NMFS-AFSC-145, Seattle, WA

Rugh D, Shelden K, Sims C, Mahoney B, Smith B, Litzky L, Hobbs R (2005) Aerial surveys of belugas in Cook Inlet, Alaska, June 2001, 2002, 2003, and 2004. US Dept Commerce. NOAA Tech Memo NMFS-AFSC-149, Seattle, WA

Shelden K, Rugh D, Mahoney B, Dahlheim M (2003) Killer whale predation on belugas in Cook Inlet, Alaska: implications for a depleted population. Mar Mamm Sci 19: $529-544$

Editorial responsibility: Helene Marsh, Townsville, Queensland, Australia
Shelden K, Moore S, Waite J, Wade P, Rugh D (2005) Historic and current habitat use by North Pacific right whales Eubalaena japonica in the Bering Sea and Gulf of Alaska. Mammal Rev 35:129-155

Stacey P, Taper M (1992) Environmental variation and the persistence of small populations. Ecol Appl 2:18-29

- Vos D, Shelden K (2005) Unusual mortality in the depleted Cook Inlet beluga (Delphinapterus leucas) population. Northwest Nat 86:59-65

Wirsing A, Heithaus M, Frid A, Dill L (2008) Seascapes of fear: evaluating sublethal predator effects experienced and generated by marine mammals. Mar Mamm Sci 24:1-15

Submitted: January 5, 2010; Accepted: May 23, 2010

Proofs received from author(s): June 17, 2010 